\title{
Accessory Head of Flexor Pollicis Longus Muscle and its Significance in Anterior Interosseous Nerve Syndrome: Case Report and Review
}

\author{
Cabeza Accesoria del Músculo Flexor Largo del Pulgar y su Significancia \\ en el Síndrome del Nervio Interóseo Anterior. Reporte de Caso y Revisión
}

"Bhagath Kumar Potu; *Vasavi Rakesh Gorantla; *Thejodhar Pulakunta;

"M. S. Rao; "Mamatha T.; "*Nkata Ramana Vollala \& ${ }^{* * *}$ Nayak. S. R.

POTU, B. K.; GORANTLA, V. R.; PULAKUNTA, T.; RAO, M. S.; MAMATHA, T.; VOLLALA, V. R. \& NAYAK, S. R. Accessory head of flexor pollicis longus muscle and its significance in anterior interosseous nerve syndrome: Case report and review. Int. J.Morphol., 25(4):911-914, 2007.

SUMMARY: During the laboratory dissection of the fore arm, an accessory head of flexor pollicis longus muscle has been observed unilaterally in the right upper limb of a male cadaver. It took its origin from the under surface of flexor digitorum superficialis muscle just distal to the origin of this muscle from medial epicondyle. On further dissection we have noticed that, the accessory belly was running downwards to the medial aspect of the tendon of flexor pollicis longus muscle for its insertion. Its possible role in anterior interosseous syndrome is discussed in detail with a brief review.

KEY WORDS: Anatomy; Anatomical variation; Flexor pollicis longus muscle.

\section{INTRODUCTION}

The anterior interosseous nerve syndrome (AINS) is a relatively rare but well-described clinical entity. It is characterized by pure weakness of the flexor pollicis longus (FPL), the flexor digitorum profundus muscles (FDP) of the index and middle fingers, and the pronator quadratus (PQ) muscle of the forearm, producing a square pinch deformity (Spinner \& Spencer, 1974; Hill et al., 1985; Proudman \& Menz, 1992). This is a compressive neuropathy, caused by compression of the anterior interosseous nerve (AIN) by any of several structures (Hill et al.; Dellon \& Mackinnon, 1987; Proudman \& Menz). The anterior interosseous nerve (AIN) branches off from the median nerve in the distal part of cubital fossa and traverses down the forearm to supply the three muscles of the forearm.

The FPL is a deep muscle of the forearm that originates from the anterior surface of the radius and adjacent interosseous membrane and inserts into the base of the distal phalanx of the thumb. Attaching to the ulnar border of the
FPL is a muscle belly, named variously the accessory head of the FPL (AHFPL), Gantzer's muscle, or occasional head. This variant muscle belly may be one of the structures that compress the anterior interosseous nerve causing AINS (Dellon \& Mackinnon; Hemaddy et al., 1993; Al-Qattan, 1996; Shirali et al., 1998; Tabib et al., 2001). The prevalence of the AHFPL was reported variously as $73.7 \%$ (Mangini, 1960), 45\% (Dellon \& Mackinnon), 52\% (Al-Qattan), and $55 \%$ (Shirali et al.). It originated from medial epicondyle of the humerus (Mangini; Dellon \& Mackinnon; Al-Qattan), coronoid process (Mangini) and medial epicondyle and coronoid process (Mangini; Dellon \& Mackinnon; AlQattan).

The insertion was reported to attach to the ulnar border of the FPL (Al-Qattan; Shirali et al.). The nerve supply was from and a branch of the AIN. The relationship between the AIN and the AHFPL was variously reported. By one account, the muscle was between the median nerve and the

\footnotetext{
* Department of Anatomy, Centre for Basic Sciences, Kasturba Medical College, Manipal, Karnataka, India.

** Department of Anatomy, Malaka Manipal Medical College, Manipal, Karnataka, India.

${ }^{* * *}$ Department of Anatomy, Centre for Basic Sciences, Kasturba Medical College, Mangalore, Karnataka, India.
} 
AIN, with the median nerve lying anteriorly and the AIN posteriorly to the muscle (Mangini \& Mackinnon; Hemaddy et al.). Another report stated that the AHFPL was anterior to the AIN (Shirali), whereas others stated it was posterior to the median nerve and AIN (Dellon \& Mackinnon; Al-Qattan).

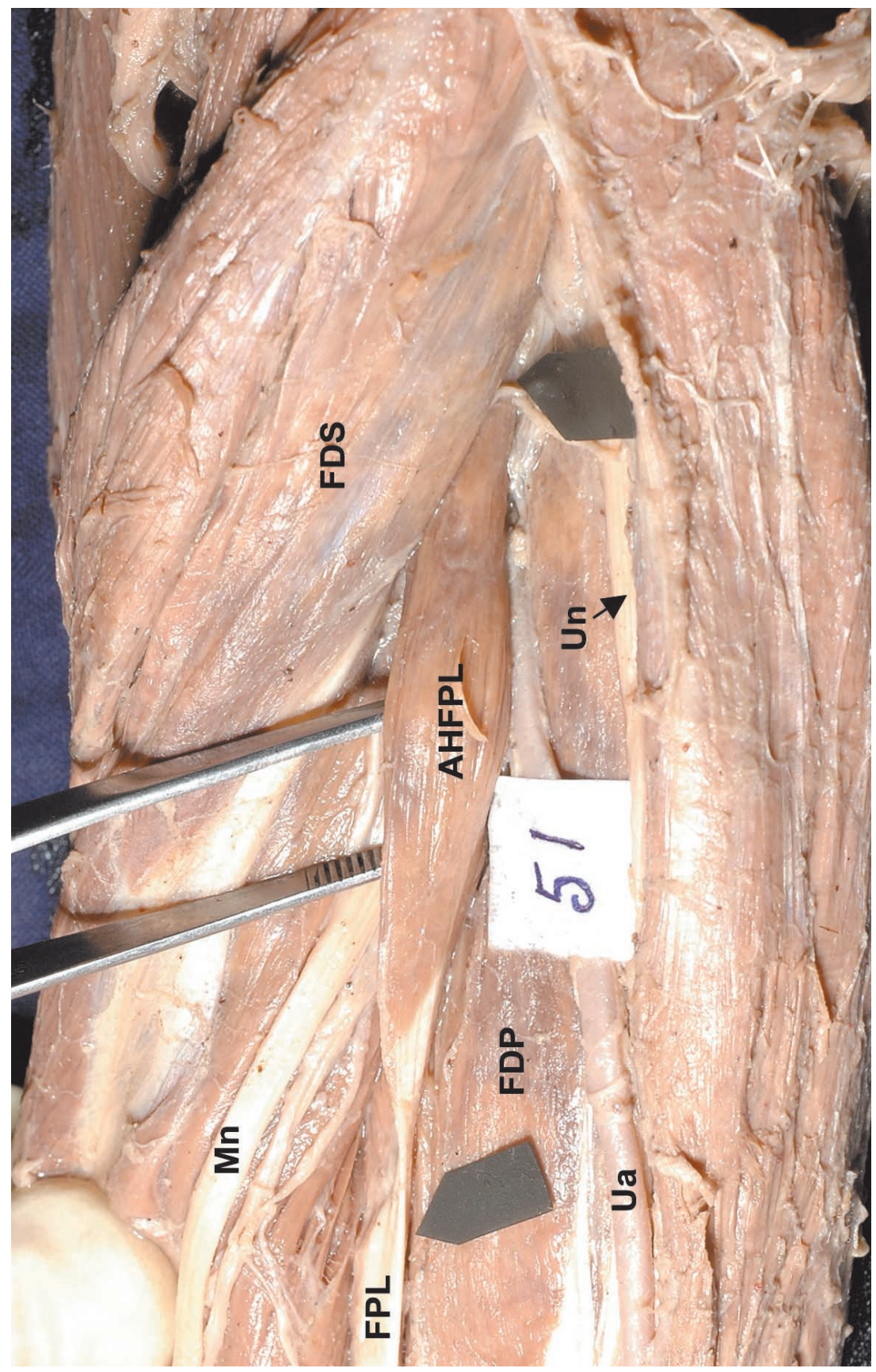

Fig. 1. Anterior view of right fore arm showing the origin and insertion of accessory head of flexor pollicis longus muscle. AHFPL accessory head of flexor pollicis longus; FPL, flexor pollicis longus, muscle; FDP, flexor digitorum profundus muscle; $\mathrm{Mn}, \mathrm{Me}-$ dian nerve; Un, Ulnar nerve; Ua, Ulnar artery.

\section{CASE REPORT}

In the routine dissection of right upper limb of 56 year old male cadaver in Department of Anatomy, K.M.C, Manipal, we observed an accessory belly, which took its origin from the under surface of flexor digitorum superficialis muscle just digital to the origin of this muscle from medial epicondyle. On further dissection we have noticed that, the accessory belly was running downwards to the medial aspect of the tendon of flexor pollicis longus muscle for its insertion. The insertion was seen at the junction between proximal and middle thirds of forearm (Fig. 1.).

The following are appropriate sizes of part described.

Muscle length $6.2 \mathrm{~cm}$, tendon length 2.6 $\mathrm{cm}$, muscle width (at proximal portion) $1.2 \mathrm{~cm}$, tendon width $0.35 \mathrm{~cm}$.

\section{DISCUSSION}

When the AHFPL is present, it is more likely to occur bilaterally then unilaterally, similar to the findings of Jones \& Abrahams, 1997 and Hemaddy et al.. Moreover, the prevalence of $62.1 \%$ $(149 / 240)$ is close to that of Hemaddy et al. and $\mathrm{Oh}$ et al., 2000, but differs from that of Mangini; Dellon \& Mackinnon, ; Al-Qattan,1996; Jones \& Abrahams and Shirali et al. Based on the literature, however, it seems that AHFPL can be found in $>50 \%$ of individuals worldwide. Morphologically, most AHFPL have their origin at the medial epicondyle (Mangini; Dellon \& Mackinnon; Hemaddy et al.; AlQattan; Jones \& Abrahams; Shirali et al.; Oh et al.), but without double origin of medial epicondyle and coronoid process as reported by Mangini, Hemaddy et al., Al-Qattan; Jones \& Abrahams. The insertion was at the ulnar border of FPL like all other studies.

Regarding the relationship between the AHFPL and AIN, we found the nerve running posterior to the belly. 
This follows the reports of Mangini; Hemaddy et al.; Jones \& Abrahams; Shirali et al.; Oh et al. where the nerve ran posterior to the belly. It also differed from the reports of Dellon \& Mackinnon and Al-Qattan; stating that the nerve passed anteriorly in front of the muscle belly.

It would seem plausible that AINS would be more likely to occur when the nerve passes posterior to the belly of the AHFPL. A complete AINS would be from Type III relationship where the whole nerve passes posteriorly underneath the belly causing weakness in the FPL, FDP of the index and middle fingers, and the pronator quadratus muscles. An incomplete AIN syndrome may also occur in this instance, however, as reported by Tabib et al. Incomplete type is likely to occur in Type IV relationship where only the medial branch of the AIN to FDP of index and middle fingers passing underneath the belly is compressed, whereas the lateral branch to FPL running alongside the belly is not. In the incomplete type of AINS, muscular weakness should be present only in the FDP although according to Hill et al. weakness was present in either FPL or FDP. This could be due to a compression of the lateral branch by other structures such as a fibrous arcade of FDS.

The occurrence of the belly of AHFPL is possibly from the development of the common flexor mass in the embryo, which differentiates into superficial and deep layers.
The deep layer further develops into FDP, FPL, and pronator quadratus muscle, but incomplete differentiation creates the AHFPL (Hollinshead, 1964; Jones \& Abrahams). The occurrence of an accessory head of FDP in Mangini; Jones \& Abrahams, 1997; and our report, all seem to attest to this hypothesis.

Mangini suggested that contracture of AHFPL may be present in patients with contracture of the thumb that do not correspond to the level of injury. This is in agreement with Kaplan's report, 1984 (as cited by Al-Qattan) of flexion contracture of the thumb long after a fracture-dislocation of the elbow in a child with scar contracture of soft tissue around the origin of AHFPL. We conclude that injury of this muscle belly may be followed by a secondary contracture, resulting in check reign effect in the thumb. This may help to remind a surgeon carrying out an anterior approach in the forearm to try to avoid such an injury.

\section{ACKNOWLEDGEMENTS}

Authors would like to thank Dr. Narga Nair, HOD of Anatomy for her support. We also thank Dr.Thejodhar, Assistant Professor, Department of Anatomy for his cooperation.

POTU, B. K.; GORANTLA, V. R.; PULAKUNTA, T.; RAO, M. S.; MAMATHA, T.; VOLLALA, V. R. \& NAYAK, S. R. Cabeza accesoria del músculo flexor largo del pulgar y su signficancia en el síndrome del nervio interóseo anterior. Reporte de caso y revisión. Int. J. Morphol., 25(4):911-914, 2007.

RESUMEN: Durante una disección en el laboratorio se encontró en el antebrazo derecho de un cadáver de sexo masculino una cabeza accesoria del músculo flexor largo del pulgar. Ésta se originaba de la superficie profunda del músculo flexor superficial de los dedos, inmediatamente distal al origen de este músculo en el epicónddilo medial. El vientre accesorio se dirigía hacia abajo medial al tendón del músculo flexor largo del pulgar hasta su inserción. Se discute detalladamente su posible rol en el síndrome interóseo anterior.

PALABRAS CLAVE: Anatomía; Variación anatómica; Músculo flexor largo del pulgar.

\section{REFERENCES}

Al-Qattan, M. M. Gantzeis muscle: an anatomical study of the accessory head of the flexor pollicis longus muscle. J. Hand Surg., 21B:269-70, 1996.

Dellon, A. L. \& Mackinnon, S.E. Musculoaponeurotic variations along the course of the median nerve in the proximal forearm. J. Hand Surg., 12B:359-63, 1987.

Hemaddy, M.V.; Subramanya, A.V.; Mehta, I. M.
Occasional head of flexor pollicis longus muscle: a study of its morphology and clinical significance. $J$. Postgrad., Med.39:14-6, 1993.

Hill, N. A.; Howard, F. M. \& Huffer, B.R. The incomplete anterior interosseous nerve syndrome. J. Hand Surg., 10A:4-16, 1985.

Hollinshead, W. H. Anatomy for surgeons. New York, Harper \& Row, 1964. V. 3. p. 412. 
POTU, B. K.; GORANTLA, V. R.; PULAKUNTA, T.; RAO, M. S.; MAMATHA, T.; VOLLALA, V. R. \& NAYAK, S. R. Accessory head of flexor pollicis longus muscle and its significance in anterior interosseous nerve syndrome: Case report and review. Int. J. Morphol., 25(4):911-914, 2007.

Jones, M. \& Abrahams, P.H. Incidence and morphology of accessory heads of flexor pollicis longus and flexor digitorum profundus (Gantzer's muscle). J. Anat., 191:451-5, 1997.

Kaplan, E. B. Correction of a disabling contracture of the thumb. BUII Hosp. Joint Dis., 3:51-4, 1942.

Mangini, U. Flexor pollicis longus muscle J. Bone Joint Surg., 42A:467-70, 1960.

Oh, C. S.; Chung, I. H. \& Koh, K. S. Anatomical study of the accessory head of the flexor pollicis longus and the anterior interosseous nerve in Asians. Clin. Anat., 13:4348,2000 .

Proudman, T. W. \& Menz, P. J. An anomaly of the median artery associated with the anterior interosseous nerve syndrome. J. Hand Surg., 17B:507-9, 1992.

Shirali, S.; Hanson, M.; Branovacki, G.; Gonzalez, M. The flexor pollicis longus and its relation to the anterior and posterior interosseus nerve. J. Hand Surg., 23B:170-2, 1998.

Spinner, M.; Spencer, P.S. Nerve compression lesions of the upper extremity: a clinical and experimental review. Clin. Orthop., 104:46-67, 1974.

Tabib, W.; Aboufarah, F. \& Asselineau, A. Compression of the anterior interosseous nerve by Gantzer's muscle. Chir. Main, 20:241-6, 2001.
Correspondence to:

Vasavi Rakesh Gorantla

Department of Anatomy,

Centre for Basic Sciences

Kasturba Medical College, Manipal,

Karnataka, 576104

INDIA

Ph: 91-820 $2922327(\mathrm{O})$

Fax: 91-820 2571927

Email: gorantla55@gmail.com

Received: 13-06-2007

Accepted: 03-09-2007 